\title{
Contractual Penalties in Australian LAW AfTER ANDREWS: AN OPPORTUNITY MISSED
}

\section{ANTHONY GRAY*}

This article considers the extent to which an Australian court might be willing to declare a contractual clause to be a 'penalty', and so not be enforceable. A recent High Court decision takes a broader view of the courts' jurisdiction to relieve against 'penalties' than has previously been the case. This article has two purposes; first, it critically considers whether the Court's position is correct, having regard to the long history and rationale for the rule. Secondly, it considers whether the doctrine forbidding penalties in contracts remains an appropriate stand-alone doctrine in contemporary contract law, or whether a recasting of the law in this area is desirable. It concludes that the High Court missed an opportunity to consider more thoroughly the reform of the penaltyliquidated damages distinction, and should have subsumed that principle within the organising principle of unconscionability.

\section{INTRODUCTION}

In the recent High Court decision in Andrews $v$ Australia and New Zealand Banking Group Ltd, ${ }^{1}$ the High Court clarified the meaning of the word 'penalty' in the context of a contract. Traditionally, contract law has distinguished, in dealing with clauses providing for the consequences of nonperformance of contractual obligations, between clauses that could fairly be described as 'liquidated damages' clauses, and clauses that could fairly be described as 'penalties'. 2 In essence, the former were enforceable; the latter were not.

The rule forbidding enforcement of 'penalties' in contracts could be seen as an anomaly in the rules of contract law, given the broad acceptance of the principle of freedom of contract, and basic nature of a contract as a bargain

\footnotetext{
* Professor of Law and Deputy Head, USQ Law School, B Bus (Acc), LLB (Hons), LLM, Grad Dip Leg Prac, PhD.

${ }^{1}$ (2012) 86 ALJR 1002 ('Andrews').

${ }^{2}$ The difference between the two will be elaborated upon below.
} 
between rational utility maximisers. It has been accepted that the courts should, in most cases, uphold a contract as an efficient exchange of promises, reflecting parties' rational decisions about risk and return. ${ }^{3}$ An agreement between the parties regarding the consequences of breach should perhaps be lauded on the basis that it reduces transaction costs associated with breach, and might respect the economic notion of 'efficient' breach. The rule forbidding enforcement of penalties can also be seen as anomalous in light of the traditional rule of contract that it is not part of the courts' role in applying contractual promises to assess (in a common law context) the adequacy of consideration moving from one party to the other. ${ }^{4}$ (The noting of these principles should not be taken to imply that the author is against the rule against penalties. Rather, it is helpful to consider the specific issues raised in Andrews in the context of the broader structure of the 'law of contract'.)

\section{History of the LaW Regarding Contractual Penalties Pre-Andrews}

\section{A International Position}

The English background ${ }^{5}$ to the law regarding contractual penalties developed as a response to the use of 'conditional bonds' to avoid rules prohibiting usury, and to provide a means to enforce promises. ${ }^{6}$ Typically, the debtor would promise to pay a certain sum of money at a future date to the creditor. The arrangement was that if the debtor performed specified obligations ('the

\footnotetext{
${ }^{3}$ Paula Baron, 'Shells of Steel and Bodies of Pulp: Commercial Man, Commercial Morality' (1999) 11 Law in Context 3, 11; Geoffrey Kuehne, 'Implied Obligations of Good Faith and Reasonableness in the Performance of Contracts: Old Wine in New Bottles?' (2006) 33 University of Western Australia Law Review 63, 98.

${ }^{4}$ Barba v Gas \& Fuel Corp of Victoria (1976) 136 CLR 120. As Rubin points out, if the court wishes to protect contracting parties from their own errors, a more obvious place to interfere would be in the amount of the contract, rather than a pre-agreed clause regarding damages to be paid upon breach: Paul H Rubin, 'Unenforceable Contracts: Penalty Clauses and Specific Performance' (1981) 10 Journal of Legal Studies 237, 242; Kenneth W Clarkson, Roger LeRoy Miller and Timothy J Muris, 'Liquidated Damages v Penalties: Sense or Nonsense?' (1978) Wisconsin Law Review 351, 357.

${ }^{5}$ The author is indebted to the following sources in making this brief summary of the historical development: Charles Calleros, 'Punitive Damages, Liquidated Damages and Clauses Pénales in Contract Actions: A Comparative Analysis of the American Common Law and the French Civil Code' (2007) 32 Brooklyn Journal of International Law 67, 74-6; William Newland, 'Equitable Relief Against Penalties' (2011) 85 Australian Law Journal 434, 439-41; A W B Simpson, 'The Penal Bond With Conditional Defeasance’ (1966) 82 Law Quarterly Review 392; Michael Mossy Christovich and Thomas J R Stadnik, 'Judicial Modification of Penal Clauses - A Survey of Recent Developments’ (1979) 53 Tulane Law Review 523.

${ }^{6}$ Newland, above n 5, 439; Calleros, above n 5, 75.
} 
main agreement'), their obligation to pay the certain sum of money was discharged. Such an arrangement provided a type of security for the creditor that the debtor would fulfil their obligations under the main agreement. Procedurally, it was simpler for the creditor to obtain payment of the promised amount of money (action on a debt) than to enforce the main agreement (action on a breach of covenant). Difficulties began to surface with these arrangements because creditors insisted on larger and larger sums to be paid at a future date in order to secure performance; these sums became unrelated and disproportionate to the loss that the creditor could conceivably suffer in the event that the debtor did not meet the obligations under the main agreement. The argument could be made that such disparity was in itself usurious. ${ }^{7}$

While the common law courts continued to uphold these arrangements, in the $16^{\text {th }}$ century, courts of equity began to provide relief against such arrangements, for example where the debtor made good the default or compensated the creditor for actual losses occasioned by the breach. ${ }^{8}$ Examples of this included cases where the debtor's conduct was 'negligent, if trifling and unintentional'. ${ }^{9}$

The discussion took place in the context of a breach of contract by the debtor. For instance it was stated that:

It is a common case to give relief against the penalty of such bonds to perform covenants etc and to send it to a trial at law to ascertain the damages in a quantum damnificatus. ${ }^{10}$

Sir George Cary summed it up thus:

If a man be bound in a penalty to pay money at a day and place, by obligation, and intending to pay the same, is robbed by the way, or hath intreated by word some other respite at the hands of the obligee, or cometh short of the place by any misfortune, and so failing of the payment, doth nevertheless provide and tender the money in short time after; in these, and many such like cases, the Chancery will compel the obligee to take his principal, with some reasonable consideration of his damages (quantum expediat) for if this was not so, men would do that by covenant which they

\footnotetext{
7 Joseph Biancalana, 'Contractual Penalties in the King's Court 1260-1360' (2005) 64 Cambridge Law Journal 212, 223.

${ }^{8}$ Newland, above n 5, 441; Christovich and Stadnik, above n 5, 530.

${ }^{9}$ William H Loyd, 'Penalties and Forfeitures before Peachy $v$ The Duke of Somerset' (1916) 29 Harvard Law Review 118, 125.

${ }^{10} 1$ Equity Cases, Abr, 91: Hall v Higham 3 Ch Rep 3 (1663); Wilson v Barton, Nelson 148 (1671); Friend $v$ Burgh, Finch 437 (1679).
} 
now do by bond ... the like favour is extendable against them that will take advantage upon any strict condition, for undoing the estate of another in lands, upon a small or trifling default. ${ }^{11}$

These equitable principles were followed by the common law courts, ${ }^{12}$ and were subsequently enshrined in legislation. The legislative provisions again proceeded on the basis that the jurisdiction to relieve against penalties would be exercised in favour of a person who had technically breached obligations under a contract. $^{13}$

The starting point of the semi-modern jurisprudence on the law of penalties is often taken to be the House of Lords decision in Dunlop Pneumatic Tyre Co Ltd $v$ New Garage \& Motor Co Ltd. ${ }^{14}$ The well-known facts involved an agreement between the parties for the supply by Dunlop of tyres and associated products, on various terms including prohibitions on the purchaser re-selling the products below a certain price, prohibitions on the purchaser onselling the product to certain parties, and prohibitions on the purchaser altering the marks on the goods. The contract provided that, in the event of the purchaser's breach, the purchaser would pay the sum of five pounds for each tyre sold pursuant to such action (the 'liquidated damages clause'). The purchasers breached the agreement by selling tyres below the seller-mandated price, raising the issue of the enforceability of the liquidated damages clause. In deciding that the clause was in fact a liquidated damages clause and was therefore enforceable, rather than a penalty clause which would not have been enforceable, Lord Dunedin made many important points. These are worth

\footnotetext{
${ }^{11}$ Anonymous [1557] Eng R 15; (1557-1602) Cary 2; 21 ER 1 (C). There may be some continuing link between usury and the development of the law in this direction, since it has been argued that to the extent that the disputed clause was designed to compensate the innocent party for breach by the other, the clause was not considered usury and so was enforceable: Biancalana, above n 7, 223.

${ }^{12}$ See Kemble v Farren (1829) 130 ER 1234, 1237 (CP) in the context of a comedian's contract to perform four seasons at a theatre for less than $£ 4$; the contract provided that failure to perform would render him liable to pay £1000. This was struck out as an 'unreasonable' penalty in that common law case.

${ }^{13}$ For example, Charles Milson's Estate: Sale of Land for Payment of Debts and Legacies and Purchase of Land for Edward Milson 1696, 8 \& 9 Wm 3 c 12 referred to actions on any bonds for 'non-performance' of any covenant where the plaintiff had received judgment in its favour, such judgment being suspended if, prior to execution, the defendant paid damages assessed on the basis of the 'breaches of such covenants', together with costs. Another statute, Baldwin and William Malett's Estate: Payment of Baldwin's Debts to the Crown as he was Receiver General for Somerset and Bristol, and Settling the Residue on William 1704, 3 \& 4 Ann c 16, referred to an action upon a bond, providing relief where the defendant had not strictly met the conditions of the agreement, but was willing to comply substantially with its obligations.
}

${ }^{14}$ [1915] 1 AC 79 ('Dunlop’). 
pointing out since they form the basis of much of the Anglo-Australian common law since this time. They can be summarised as follows:

a) The decision whether a clause is in fact a liquidated damages clause or a penalty is a matter of substance not form; the words used by the parties to describe the clause are not conclusive; ${ }^{15}$

b) '[A] penalty is a payment of money stipulated as in terrorem of the offending party; the essence of liquidated damages is a genuine covenanted pre-estimate of damage'; ${ }^{16}$

c) The question is to be judged as at the time of the making of the contract, not the time of breach; ${ }^{17}$

d) The amount will be a penalty 'if the sum stipulated for is extravagant and unconscionable in amount in comparison with the greatest loss that could conceivably be proved to have followed from the breach'; ${ }^{18}$

e) It will 'be a penalty if the breach consists only in not paying a sum of money, and the sum stipulated is a sum greater than the sum which ought to have been paid'; ${ }^{19}$

f) 'There is a presumption ... that it is a penalty when "a single lump sum is made payable, by way of compensation, on the occurrence of one or more or all of several events, some of which may occasion serious and others but trifling damage", ; ${ }^{20}$ and

g) The amount stated can be seen to be a genuine pre-estimate of damage although the consequences of the breach are such that precise pre-estimation is difficult or impossible. ${ }^{21}$

Lord Parker agreed with (g), stating that 'where the damages which may arise out [of] a breach of contract are in their nature uncertain, the law permits the

\footnotetext{
${ }^{15}$ Ibid 86 (Lord Dunedin).

16 Ibid.

${ }^{17}$ Ibid 87 (citing Public Works Commissioner v Hills [1906] AC 368 and Webster v Bosanque [1912] AC 394).

${ }^{18}$ Dunlop [1915] 1 AC 79, 87.

${ }^{19}$ Ibid (citing Kemble v Farren 6 Bing 141).

${ }^{20}$ Ibid (quoting the judgment of Lord Watson in Lord Elphinstone $v$ Monkland Iron and Coal Co (1886) 11 App Cas 332, 345).

${ }^{21}$ Dunlop [1915] 1 AC 79, 87-8.
} 
parties to agree beforehand the amount to be paid on such breach' ${ }^{22}$ Lord Parmoor stated that contracting parties were competent to agree beforehand on 'the amount of damages, uncertain in their nature, payable on the breach of a contract'. ${ }^{23}$ Another judge in the case, Lord Atkinson emphasised the nature of a penalty as an amount that was unconscionable or extravagant 'having regard to any possible amount of damage likely to have been in the contemplation of the parties when they made the contract'. ${ }^{24}$ Of Lord Dunedin's points, (b), (c), (d), (e) and (g) expressly confirm the notion of the liquidated damages/penalty debate occurring in the context of a breach of contract. $^{25}$ Two of the other three judges also spoke of the liquidated damages/penalty debate occurring in the context of a breach of contract, and the words of Lord Atkinson implicitly alluded to breach of contract. No suggestion appeared in this case that a clause might be deemed to be a 'penalty' other than in the context of a breach of contract. ${ }^{26}$

Other cases in that era reflected similar sentiments. In Clydebank Engineering and Shipbuilding Co Ltd v Castaneda, the Earl of Halsbury LC described a liquidated damages clause as an agreement that 'such and such a sum shall be damages if I break my agreement'. ${ }^{27}$ Lord Davey described a penalty as an amount so extravagant that it could not be regarded as 'damages for any possible breach' within the parties' contemplation. ${ }^{28}$ The Privy Council, in Webster $v$ Bosanquet in considering a clause forbidding one of the parties to sell tea to a third party without the other contracting party's consent, found unanimously that, when the contract was made, 'it was impossible to foresee the extent of injury which might be sustained by the plaintiff if sales of the tea were made to third parties without his consent'. ${ }^{29}$ In other words, the validity of the clause was assessed in the context of a breach of agreement by the party seeking relief. The Council in Public Works Commissioner v Hills stated that

\footnotetext{
${ }^{22}$ Ibid 97.

${ }^{23}$ Ibid 100.

${ }^{24}$ Ibid 95. This bears close resemblance to the classic test for determining damages for breach of contract, the damages covering damage arising from the ordinary course of things or damage that 'may reasonably be supposed to have been in the contemplation of both parties, at the time they made the contract, as the probable result of the breach of it': Hadley $v$ Baxendale (1854) 9 Ex 341, 354.

${ }^{25}$ Point (b) uses the words 'offending party'; the other subsections expressly use the word 'breach'. In relation to (f), the reference to 'events' might be taken, given the context of all the other points, to mean breaches of contract.

${ }^{26}$ The continuing correctness and applicability of this precedent in Australia was confirmed by six members of the High Court in Ringrow Pty Ltd v BP Aust Pty Ltd (2005) 224 CLR 656, 663 ('Ringrow').

${ }^{27}$ [1905] AC 6, 11 ('Clydebank Engineering').

${ }^{28}$ Ibid 16.

${ }^{29}$ [1912] AC 394, 398.
} 
a true liquidated damages clause reflected the innocent party's 'probable or possible interest in the due performance of the principal obligation'. 30

A majority of the House of Lords in Bridge $v$ Campbell Discount Co Ltd proceeded on the basis that the context in which a discussion about the distinction between liquidated damages and penalties arose was a breach of contract by the party seeking relief. ${ }^{31}$ The majority included Lord Morton, ${ }^{32}$ Lord Radcliffe, ${ }^{33}$ and Lord Devlin. ${ }^{34}$ Viscount Simonds found that the hirer did not breach the agreement. ${ }^{35}$ No question of a penalty arose, because the hirer was exercising a right to terminate the contract. It was only the remaining judge, Lord Denning, who specifically found that the court's power to relieve against penalties was not limited to cases where the party seeking relief was in breach. ${ }^{36}$ That decision flew in the face of many years of court precedent that had found to the contrary, and the reasoning of Lord Denning in that case is, with respect, open to serious challenge. ${ }^{37}$

\footnotetext{
${ }^{30}$ [1906] AC 368, 376.

${ }^{31}$ [1962] AC 600 ('Bridge').

32 Ibid 615: 'The appellant has clearly committed a breach of the hire-purchase agreement by failing to pay the subsequent instalments, and it becomes necessary to consider whether the payment stipulated ... was a penalty' (emphasis added).
}

${ }^{33}$ Ibid 621: 'when a question arises as to whether a sum stipulated to be payable under a contract is liquidated damages for a breach of that contract, or some part of it, or is a penalty attached to that breach' (emphasis added).

${ }^{34}$ Ibid 632 (expressing agreement with the judgment of the other two judges).

${ }^{35}$ Ibid 613.

${ }^{36}$ Ibid 630 .

${ }^{37}$ For instance, Lord Denning sought to establish a category of cases where courts had provided relief against penalties for non-performance of a condition, a category that Lord Denning distinguished from those cases where penalties were awarded for breach of contract. The example that he cited involved a mortgage which provided for payments to be made by a certain date. Failure to pay by that date meant that the property was lost to the party in breach. Lord Denning stated that courts of equity 'always' relieved the mortgagor in the case of nonperformance of this condition (ibid). Whilst the author would agree that equity courts would often grant relief in such cases, he would respectfully differ from Lord Denning in categorising cases such as this as cases of 'non-performance of a condition'. These cases could also be seen as cases where the party seeking relief had breached the agreement by not performing the obligations on time. The other example Lord Denning gave involved a penalty bond which provided that the obligor bound himself by his bond to pay a specified sum, subject to an exception if the obligor was of good behaviour (Lord Denning's example). Lord Denning stated that equity would be prepared to provide relief against such a clause on the basis that it was a penalty, and asserted that in many such cases there was no covenant by the obligor to be of good behaviour, thus establishing that relief against penalties was not conditional on proof of breach of contract. The present author would respond, however, that the clear purpose of such a clause was to require the obligor to perform the main obligation; it could be argued that the obligor's failure to be of 'good behaviour' was in essence (if not, according to the technical wording of the contract, due to concerns about usury laws) a breach 
Further endorsement of the orthodox position appeared in Export Credits Guarantee Department v Universal Oil Products Co where Lord Roskill, with whom all the other Lords agreed, stated:

One purpose, perhaps the main purpose, of the law relating to penalty clauses is to prevent a plaintiff recovering a sum of money in respect of a breach of contract committed by a defendant which bears little or no relationship to the loss actually suffered by the plaintiff as a result of the breach by the defendant. ${ }^{38}$

The position in the United Kingdom reflects the law in Canada ${ }^{39}$ and in the United States. Section 2-718(1) of the United States Uniform Commercial Code refers to the practice of damages for breach by either party being liquidated in the agreement, at a level considered reasonable in light of anticipated harm. It states that a term fixing an unreasonably large liquidated damages amount is void as a penalty. ${ }^{40}$ The above position regarding penalties in this context also reflects the understanding of equity's role in providing relief against penalties and forfeitures at a more general level. ${ }^{41}$

of contract. Lord Denning's other main point, about the supposed 'inequity' of providing equitable relief only when the party seeking relief had breached the contract, can be met with the argument, discussed further below, that the law in this area should be subsumed into the general law of unconscionability. In applying this doctrine, all of the circumstances of the case would be taken into account, including the behaviour of both parties to the contract.

${ }^{38}$ [1983] 1 WLR 399, 403 ('Export Credits'). See also Lucinda Miller, 'Penalty Clauses in England and France: A Comparative Study' (2004) 53 International and Comparative Law Quarterly 79, 94: 'It is only where there is a breach of the contract that the law relating to penalties is relevant. A sum due on the occurrence of any other event cannot therefore be covered under these rules.'

39 'A penalty is the payment of a stipulated sum on breach of the contract': Canadian General Electric Co v Canadian Rubber Co (1915) 52 SCR 349. For more detail on the Canadian jurisprudence, see Paul-Erik Veel, 'Penalty Clauses in Canadian Contract Law' (2008) 66 University of Toronto Faculty Law Review 229.

${ }^{40}$ See also American Law Institute, Restatement (Second) of Contracts (1981) § 356; Wirth \& Hamid Fair Booking Inc $v$ Wirth, 192 NE 297, 301 (NY, 1934). The intention of the parties, difficulty in ascertaining damages upon breach, and the reasonableness of the amount stipulated are all relevant.

${ }^{41}$ In the leading case of Shiloh Spinners Ltd $v$ Harding [1973] AC 691, 723-4, Lord Wilberforce (with whom Viscount Dilhorne, Lord Pearson, and Lord Kilbrandon agreed) referred to equity's jurisdiction in the following terms: '[I]n appropriate and limited cases to relieve against forfeiture for breach of covenant or condition ... the word "appropriate" involves consideration of the conduct of the applicant for relief, in particular whether his default was wilful, of the gravity of the breaches, and of the disparity between the value of the property of which forfeiture is claimed as compared with the damage caused by the breach' (emphasis added); to like effect Lord Simon (at 726-7). 


\section{B $\quad$ Australia}

The issue of the context in which the penalty/liquidated damages question can arise has been considered by various Australian High Court authorities. One of them was IAC (Leasing) Ltd v Humphrey, ${ }^{42}$ involving a leasing contract providing for the full amount of the lease rental to be paid upfront, subject to clauses providing for periodic payments. In the event of the lessee defaulting in making these payments, the entire sum would be immediately payable. Provision was made for the lessor to dispose of the leased goods either following breach of contract by the lessee or merely upon the contract ending by effluxion of time, and the lessee was liable to make good any shortfall that the lessor suffered as a result of the sale. This liability could accrue whether or not a breach of contract had occurred. The High Court decided, on the basis that the contract included penalties, that the lessee was not entitled to relief.

Walsh J noted that the lessee's liability to make good the shortfall upon the lessor disposing of the property could arise both where the lessee had breached the agreement, and where it had not. In that light, he considered the availability of relief against penalties. He noted that:

The view has prevailed in England that those rules [regarding penalties] may be applied in appropriate circumstances to make such a provision unenforceable, in so far as it operates, in the events which happen, as a consequence of a breach of contract, notwithstanding that the same results may be attached by the agreement to acts or events which involve no breach ... [T] here has been a preponderance of [English] opinion in favour of the view that it is only when a provision operates so that the event upon which an obligation is placed upon a party to pay a sum of money to another party to a contract is the breach by the former party of a term of the contract, that the question arises whether an obligation arising upon that event is a penal provision. Thus if a sum has become payable because a party has exercised an option given by the agreement, the exercise of which is conditional upon a payment, the view has been taken that the question of a penalty does not arise. $^{43}$

This debate also surfaced in O'Dea v Allstates Leasing System (WA) Pty Ltd, ${ }^{44}$ again involving a vehicle leasing agreement providing for a lump sum payment upfront, subject to clauses allowing periodic payments. If any of these payments were not made, or other obligations in the contract not kept,

\footnotetext{
${ }^{42}$ (1972) 126 CLR 131 ('IAC'). The discussion of liquidated damages/penalties in Boucaut Bay Co Ltd (in liq) v Commonwealth (1927) 40 CLR 98 also took place in the context of breach of contract.

${ }^{43}$ IAC (1972) 126 CLR 131, 143 (emphasis added) (Barwick CJ and McTiernan J agreeing (at 135)). Only three judges decided this case.

${ }^{44}$ (1983) 152 CLR 359 ('O'Dea').
} 
the lessor could demand the entire amount and repossess the leased vehicle. Some of these breaches could be serious; others could be trivial. The lessor could lease the vehicle to another, and the original lessee's liability would be accordingly reduced. The agreement stated that nothing in it released the original lessee from the obligation to pay all of the instalments provided for in the contract, plus reasonable costs of repossession. The lessee did not make the required payments, and the lessor repossessed the vehicle. A unanimous High Court found the lessee entitled to relief regarding the balance of unpaid rent after repossession. ${ }^{45}$

Members of the Court again alluded to the issue of whether the penalties/liquidated damages debate should occur in the context of breach. It arose in the same way as in $I A C$, in the context where the lessor's right to terminate and receive payment arose on the occurrence of various events, some of which involved the lessee breaching their obligations, and some of which did not. Gibbs CJ stated that relief against penalties was only available in the situation where the person seeking relief had breached the contract. ${ }^{46}$ Brennan $\mathrm{J}$ reached the same view, concluding that ' $\mathrm{t}$ ] he balance of opinion in this Court has favoured the view that no question of penalty arises unless the obligation to pay arises upon breach of contract'. ${ }^{47}$ Deane $\mathrm{J}$ referred with approval to the judgment of Lord Dunedin in Dunlop, which distinguished between penalties and liquidated damages in the context of breach of contract. $^{48}$

The same question of whether a penalty was available only upon a breach of contract by the party seeking a remedy arose in AMEV-UDC Finance Ltd $v$ Austin, ${ }^{49}$ where the lessee breached the agreement by failing to pay instalments by the due date. The lessor terminated the contract for this breach. Argument arose regarding whether the lessor's contractual entitlement to claim the present value of future hire charges as at the date of termination was enforceable. The majority found that the lessor was entitled only to the unpaid instalments, with interest.

The case again directly raised whether the question regarding whether a payment was a penalty arose only in the context of a breach of contract by the

\footnotetext{
${ }^{45}$ Gibbs CJ, Wilson and Deane JJ applied the penalties doctrine, Murphy J stated that the relevant provisions were unconscionable, and Brennan $\mathrm{J}$ applied the forfeiture doctrine.

${ }^{46}$ O’Dea (1983) 152 CLR 359, 367.

${ }^{47}$ Ibid 390.

${ }^{48}$ Ibid 399-400.

${ }^{49}$ (1986) 162 CLR 170 ('AMEV’).
} 
party seeking relief ${ }^{50}$ or was of broader application. Consistent with his earlier views, Gibbs CJ suggested that breach of contract was the correct context. ${ }^{51}$ Mason and Wilson JJ referred to English authority ${ }^{52}$ affirming that the doctrine of penalties has no application to a stipulation which provides for the payment of an agreed sum on the happening of a specified event other than a breach of contract'. ${ }^{3}$ Dawson J took a similar position, concluding that 'a provision calling for the payment of money by one party on the occurrence of a specified event, rather than upon breach by that party, cannot be a penalty'. ${ }^{54}$ On the other hand, Deane $\mathrm{J}$ claimed that proof of a breach of contract by the party seeking relief was not required in order to enliven the jurisdiction to set aside a clause in the contract as a penalty. ${ }^{55}$

In the most recent High Court decision prior to Andrews, all six judges reiterated this orthodox view of the penalties doctrine:

The law of penalties, in its standard application, is attracted where a contract stipulates that on breach the contract-breaker will pay an agreed sum which exceeds what can be regarded as a genuine pre-estimate of the damage likely to be caused by the breach. ${ }^{56}$

\footnotetext{
${ }^{50}$ This can include situations where the innocent party terminates the contract following breach of contract by the party now seeking relief against a 'penalty': Esanda Finance Co Ltd v Plessnig (1989) 166 CLR 131, 140 (Wilson and Toohey JJ), 147 (Brennan J), 154 (Deane J), 157 (Gaudron J).

${ }^{51} \mathrm{He}$ spoke of the definite rules governing the position of parties to a contract which contains a clause 'imposing a penalty for breach': AMEV (1986) 162 CLR 170, 176.

${ }^{52}$ Bridge [1962] AC 600; Export Credits [1983] 1 WLR 399, 402-3.

${ }^{53}$ AMEV (1986) 162 CLR 170, 184. See also Mason and Deane JJ in Legione v Hateley (1983) 152 CLR 406, 445 ('Legione'), who stated that '[a] penalty, as its name suggests, is in the nature of a punishment for non-observance of a contractual stipulation; it consists of the imposition of an additional or different liability upon breach of the contractual stipulation' (emphasis added). See further Stern v McArthur (1988) 165 CLR 489, 524: '[R]elief against the vendor's retention of the instalments of purchase money ... is in the nature of relief against a penalty because it relieves the purchaser against losing both the land and the payments he has made. Such a consequence could only be by way of punishment upon default' (emphasis added).

${ }^{54}$ AMEV (1986) 162 CLR 170, 211, also citing Bridge (1962) AC 600 and Export Credits (1983) 1 WLR 399.

${ }^{55}$ AMEV (1986) 162 CLR 170, 199.

${ }^{56}$ Ringrow (2005) 224 CLR 656, 662 [10] (emphasis added). Lest too much stock be placed in the phrase 'in its standard application', elsewhere in the judgment appears a re-affirmation of general notions of freedom of contract, and the need for caution in intervening in freely negotiated agreements (at 669). Of the judgments in Esanda Finance Corporation Ltd v Plessnig (1989) 166 CLR 131, only Deane J squarely addressed this issue, confirming the orthodox view (at 153).
} 
Academic support is overwhelmingly in favour of the view that the question of whether a damages clause is a penalty or a genuine pre-estimate of damage must occur in the context of a breach. ${ }^{57}$ Some authors have connected the law forbidding penalties with the general public policy principle that punitive damages are not payable for breach of contract. ${ }^{58}$ While this is true of punitive damages in such a context, this does not explain why punitive damages are payable in the tort context, such that (somewhat perversely) a party with claims in both contract and tort would gain an advantage, if seeking supracompensatory damages, by framing the claim in the latter. ${ }^{59}$

The matter has also been considered at state level, with references to the fact that the discussion of relief against a penalty occurs in the context of a breach of contract by the party seeking relief. ${ }^{60}$ In Interstar Wholesale Finance Pty

57 A sample includes: J W Carter and Elisabeth Peden, 'A Good Faith Perspective on Liquidated Damages' (2007) 23 Journal of Contract Law 157, 160 referring to penal imposition 'on breach'; Eric L Talley, 'Contract Renegotiation, Mechanism Design, and the Liquidated Damages Rule' (1994) 46 Stanford Law Review 1195, 1200: 'In the sixteenth century, the [English] court[s] began to intervene regularly on behalf of defaulting obligors, relieving them of excessive sums due under penal bonds' (emphasis added); Robert E Scott and George G Triantis, 'Embedded Options and the Case against Compensation in Contract Law' (2004) 104 Columbia Law Review 1428, 1441: 'By the end of the eighteenth century, common law courts had adopted the equity rule of relief from the bond where the amount owed greatly exceeded the loss to the plaintiff from the breach of the condition' (emphasis added); Charles J Goetz and Robert E Scott, 'Liquidated Damages, Penalties and the Just Compensation Principle: Some Notes on an Enforcement Model and a Theory of Efficient Breach' (1977) 77 Columbia Law Review 554, 555: ‘[T]he equity courts apparently refused enforcement when either actual or presumptive evidence of unfairness indicated that recovery would result in an "unjust, extravagant, or unconscionable quantum of damages in case of a breach"' (emphasis altered), quoting Seymour D Thompson, 'Penalties and Liquidated Damages' (1898) 46 Central Law Journal 5; Bruno Zeller, 'Penalty Clauses: Are They Governed by the CISG?' (2011) 23 Pace International Law Review 1, 1: ‘[A] penalty clause or fixed sum is a pre-determined amount of money which becomes due in the event of a breach of contract' (emphasis added); James P George, 'Reimposable Discounts and Medieval Contract Penalties' (2007) 20 Loyola Consumer Law Review 50, 59: 'Equity courts ... began enjoining penal bonds, then sending the case to trial in common law courts to determine the actual damages. This in turn led to statutes in England requiring the penal bond obligee to state the promisor's breach and then show actual damages'; Biancalana, above $n$, 223. The only article that this author found that advocates the position that a breach by the party seeking relief is not necessary is Newland, above $n$ 5, 445 .

${ }^{58}$ Carter and Peden, above n 57, 160. This justification reinforces the orthodox view that the discussion of penalties occurs in the context of a breach of contract by the party seeking relief, as the learned authors acknowledge: 'The concern of the law of penalties is to strike a satisfactory balance between freedom of contract and the ideas - based on policy and good faith - that promisees should not be permitted to recover punitive sums and that promisors not be coerced by the threat of penal imposition on breach' (emphasis added).

${ }^{59}$ Obviously, one set of facts can give rise to actions in both tort and contract: see, eg, Astley $v$ Austrust Ltd (1999) 197 CLR 1.

${ }^{60}$ See, eg, PC Developments Pty Ltd v Revell (1991) 22 NSWLR 615, 630 (Mahoney JA), 642 (Clarke J), 650 (Meagher JA). Mahoney JA dealt with the issue in most detail, reflecting that 
Ltd v Integral Home Loans Pty Ltd, ${ }^{61}$ the New South Wales Court of Appeal, applying Export Credits, found the Court's jurisdiction to intervene in such cases limited to cases where the disputed clause had been applied following a breach of contract by the party now seeking relief. This was justified on the basis of United Kingdom and Australian precedent, ${ }^{62}$ as well as the public policy of keeping commercial parties to their bargains, and keeping the doctrine within strict and clearly identifiable limits. ${ }^{63}$ A reading of the standard contracts used in Australia also tends to reflect this understanding of 'penalties'.64

In summary, the view that the application for relief against penalties in a contract must take place in the context of a breach of that contract by the party seeking relief has been established by a century of United Kingdom cases, and 40 years of High Court decisions. It is supported by United States and Canadian authority, and has enjoyed overwhelming academic support. The decision of the High Court in Andrews should be seen in this light.

\section{Andrews v Australia ANd New Zealand Banking GROUP LTD}

\section{A Decision}

In this case, the appellants challenged fees charged by the respondent for honouring unauthorised debits and accepting other irregular transactions, arguing that they were penalties. The case was run on the basis that the unauthorised debits and other irregular transactions did not amount to a breach of contract by the customer. As a result, the High Court was required squarely to address the question of whether these fees could be challenged on the basis that they were a penalty, despite the argument taking place outside the context of a breach of agreement by the parties seeking relief. The single

the jurisdiction to relieve against penalties arose in cases with respect to a requirement to pay or forfeit amounts based on an event within the responsibility of the person seeking relief.

${ }^{61}$ [2008] NSWCA 310, [112] (Allsop P, with whom Giles JA and Ipp JA agreed) ('Interstar').

${ }^{62}$ Ibid [107]-[111].

${ }^{63}$ Ibid [112].

${ }^{64}$ For instance, Standards Australia, AS 2124 (1992) (General Conditions of Contract) <http:// www.standards.org.au/Pages/default.aspx $>$ refers to liquidated damages payable if the contractor fails to reach practical completion by the due date (cl 35.6), as does AS 4000 (1997) cl 34.7 and AS 4300 (1995) cl 35.6. For a discussion of these in the context of arguments about penalties, see Richard Manly, 'The Benefits of Clauses that Liquidate, Stipulate, Pre Estimate or Agree Damages’ (2012) 28 Building and Construction Law Journal 246; Michael Hollingdale, 'Designing and Enforcing Liquidated Damages Clauses to Maximise Recovery’ (2005) 21 Building and Construction Law Journal 412. 
judge had found that an argument that a clause was a penalty could be raised only in a case where the party seeking relief had breached the contract. A unanimous High Court disagreed, finding that the doctrine of penalties could be applied in such a case. ${ }^{65}$ The High Court concluded that the New South Wales Court of Appeal was wrong in Interstar to proceed on the basis that the equitable jurisdiction to relieve against penalties had been subsumed into the common law by the Judicature Acts. ${ }^{66}$

The High Court also noted the applicants' prolix pleadings, including extensive reference to statutory material dealing with allegedly unfair or unjust transactions. The validity of such references was not a matter to be decided by the High Court. However, the Court took the opportunity to assert that their existence demonstrated 'the need for caution when dealing with the ... [common law] as if laissez faire notions of an untrammelled "freedom of contract” provide a universal legal value'. ${ }^{67}$

\section{B Critique}

Some aspects of the reasoning employed by the High Court in Andrews are challenging.

The first is the Court's observation, after referring to statutory development, that there is a need for caution when dealing with the common law in a way suggestive that an untrammelled freedom of contract is an all-encompassing value.

With respect, this may be seen to be setting up something of a 'straw person'. There is very little, if any, suggestion that an approach of untrammelled freedom of contract should be pursued as a 'universal' value of the common law. The general law of unconscionability, estoppel, non est factum, mistake, and misrepresentation is far too well established for that. What authorities have suggested in this area is that freedom of contract is an important factor to take into account when considering the extent to which courts should be prepared to intervene in the voluntary contractual arrangements of parties, a point expressly accepted by the High Court in Ringrow ${ }^{68}$ in 2005. To say that freedom of contract is an important factor, or is normally taken into account,

\footnotetext{
${ }^{65}$ The Andrews Court did not refer to the judgment of Lord Denning in Bridge [1962] AC 600, one of the few judgments in the United Kingdom that has reached the same position as it did. Nor did it rely on the judgment of Deane J in AMEV (1986) 162 CLR 170, 199, which reached the same position as in Andrews.

${ }^{66}$ Andrews (2012) 86 ALJR 1002, [60]-[63].

${ }^{67}$ Ibid [5].

${ }^{68}$ (2005) 224 CLR 656, 669.
} 
is not, of course, to say that 'untrammelled' freedom of contract should be pursued as a universal value.

Further, it is interesting to consider the other suggestion in the Court's opening statement - that the development of the common law should reflect, or be guided by, developments in statutory law. If the Court is proposing that the common law should be developed to mirror the statutory law, this would be inconsistent with earlier statements of the Court. It is possible to cite examples where the High Court has refused to develop the common law in a way that would be harmonious with the statutory law on a particular subject. ${ }^{69}$ Nor should the common law necessarily be developed so as to be harmonious with statutory law; arguably they are different jurisdictions, influenced by different sources. For example, the fact that Australian law has recognised since 1974 an action for misleading and deceptive conduct has not led (and should not necessarily have led) to development of a common law action for misleading and deceptive conduct, or a re-interpretation of the rules regarding misrepresentation so that they accord with the statutory admonition not to be misleading and deceptive. The jurisdictions are seen as complementary, with clear rules for establishing how incompatibility is to be resolved.

As a result, a cursory reference to broad developments in statutory consumer law that have rejected 'untrammelled' freedom of contract is at best, marginal to deciding the question raised in Andrews: namely, what the general law of penalties is or should be.

In considering the historical uses of bonds and conditions the High Court in Andrews determined that the condition could be an occurrence or event which need not be some act or omission of the obligor. The Court considered that some confusion had arisen over the use of the word 'condition' in such a context, $^{70}$ and that it should not be taken to mean a requirement that the person seeking relief was to perform. The Court referred to Williston's $A$ Treatise on the Law of Contracts ${ }^{71}$ in this part of its judgment. However, even the passages cited do not, with respect, support its conclusion. For instance, the Court quoted Williston as stating that the purpose of a conditional bond is to secure performance of the condition; instead of attempting to secure

\footnotetext{
${ }^{69}$ One example concerns the test to be applied in relation to a stay of proceedings. The High Court of Australia has continued to insist on the use of the 'clearly inappropriate forum' test (Voth v Manildra Flour Mills Pty Ltd (1990) 171 CLR 538), while statutes in Australia have adopted the United Kingdom position of the 'more appropriate forum': see, eg, Supreme Court (General Civil Procedure) Rules 2005 (Vic) r 7.05; Uniform Civil Procedure Rules 2005 (NSW) r 8.2. Many other examples across the law can be provided.

${ }^{70}$ Andrews (2012) 86 ALJR 1002, [34].

${ }^{71}$ Richard A Lord and Samuel Williston, A Treatise on the Law of Contracts (Lawyers Cooperative Publishing, $4^{\text {th }}$ ed, 2000).
} 
performance of the condition by exacting a promise from the obligor to perform it, the conditional bond entails an acknowledgment of indebtedness and a promise to pay the money if the condition is not performed. Whilst Williston is undoubtedly correct, the statement does not support the Court's decision that the jurisdiction to relieve against penalties applies to any breach of condition, rather than one over which the party seeking relief has the obligation.

The Court referred very briefly to Roman, Louisiana/French and German principles $^{72}$ leading up to its statement that no breach by the party seeking relief need be shown. However, none of the materials it cited dealt with this precise issue; they merely confirmed what is not disputed, which is that the courts can reconsider such a clause if the amount stated is deemed excessive. Immediately after this discussion, the Court concluded that 'the condition may be an occurrence or event which need not be some act or omission of the obligor' ${ }^{73}$ No further authority is cited for this conclusion.

It was pointed out earlier that, until this case, the orthodox view on the law of penalties was that the question of relief arose in the context of a breach of contract by the party seeking relief. That this was the position was reinforced by many authorities to which reference has been made above, including United Kingdom decisions such as Dunlop, Clydebank Engineering, Bridge, Export Credits, and Australian High Court decisions such as IAC, O'Dea, $A M E V$, Legione, and Ringrow. The result of all of these precedents was, with respect, correctly reflected in the New South Wales Court of Appeal's decision in Interstar. The only statements in any of these cases supporting the

\footnotetext{
${ }^{72}$ Andrews (2012) 86 ALJR 1002, [38]. In fact, a recent article confirms that the French position is very similar to the English; after referring to the French position, Miller states that there is 'close resemblance with the English liquidated damages clause ... [t]he clause will fix in advance the amount of damages in the event of default' (emphasis added): Miller, above n 38, 86. To like effect, see Christovich and Stadnik, above n 4, 540-1: 'Both the French and Louisiana Codes view the penal clause as compensation for the damages suffered by the creditor due to the nonexecution of the debtor's prestations' (emphasis added). Mattei claims that, as originally drafted, art 1226 of the Napoleonic Code provided that a penalty was a clause in a contract promising something in case the agreement was not performed by a party; art 1552 provided that where an agreement provided that the party who fails to perform it must pay a stated damages amount, no larger or smaller sum could be awarded. (French law has since evolved to give judges discretion to alter agreed damages clauses (art 1231)): Ugo Mattei, 'The Comparative Law and Economics of Penalty Clauses in Contracts' (1995) 43 American Journal of Comparative Law 427, 434-6. In relation to Roman law, again the High Court's interpretation of the evidence is challengeable: 'The civilian heritage of contractual penalties derives from the classical Roman poena. The poena was a "penalty agreed upon by the parties, to be paid by the debtor in the case of nonfulfillment of his obligation in due time"' (emphasis added): Christovich and Stadnik, above n 5, 524 quoting Adolf Berger, Encyclopedic Dictionary of Roman Law (1953) 634.

${ }^{73}$ Andrews (2012) 86 ALJR 1002, [39].
} 
decision taken in Andrews were those of Deane $\mathrm{J}$ in $A M E V$, and those of Lord Denning in Bridge. As a result, the High Court in Andrews significantly altered the established understanding of the law. Now, it is certainly within the prerogative of the High Court to change the law, and there are numerous examples in the High Court's history of it doing exactly that. The issue is not whether the High Court has such jurisdiction, nor its extent. Indeed, the need for ongoing refinement of principle to meet new problems and reflect societal values is argument enough not to limit the Court's power. Common law and equitable principles are not, and should not be seen to be, static, and improvement should be constantly sought.

However, where an important change is made to longstanding principle, one would expect to see a full airing of the issues, a comprehensive appraisal of the law as it existed prior to the current decision, a full consideration of reasons why the previous law is seen to be unsatisfactory, and an indication of how the new principles will create a better set of rules. Such consideration befits the final appellate court of the nation considering an important change in the law. In the area of obligations, the author would point to decisions of the High Court in cases such as Burnie Port Authority v General Jones Pty Ltd, ${ }^{74}$ Brodie v Singleton Shire Council, ${ }^{75}$ Trident General Insurance Co Ltd v McNiece Bros Pty Ltd, ${ }^{76}$ and Waltons Stores (Interstate)Ltd v Maher. ${ }^{77}$ In all of these cases, important refinements to the common law were made, but, in the author's view, they were made after a full consideration of the relevant issues, and an appraisal of the conceptual weakness and potential injustice of existing case law. In short, the case for change was made. In the author's view, the High Court in Andrews did not make its case.

In the judgment itself, which runs to approximately 14 pages in the Australian Law Journal Reports, there is a brief reference to the leading Dunlop case, ${ }^{78}$ the correctness of which had recently been reaffirmed in Australia in Ringrow. The court in Ringrow $^{79}$ extracted comments from the leading judgment in Dunlop, that of Lord Dunedin. As indicated earlier, these comments repeatedly reflect the understanding of the court's jurisdiction to relieve against penalties as arising in the context of a breach by the party seeking relief. With respect, the Court in Andrews made no attempt to reconcile the

\footnotetext{
74 (1994) 179 CLR 520 (subsumption of principles of strict liability into the general law of negligence in Australia).

75 (2001) 206 CLR 512 (abolition of highway authority immunity for non-feasance in Australia).

${ }^{76}$ (1988) 165 CLR 107 (privity).

77 (1988) 164 CLR 387.

${ }^{78}$ [1915] 1 AC 79, [69]-[77].

${ }^{79}$ (2005) 224 CLR 656, 662.
} 
repeated reference in the Dunlop judgment to such jurisdiction being limited to cases of breach by the party seeking relief, with its finding here that the court's jurisdiction was not so limited. The Court did not explain how the English courts in cases such as Clydebank Engineering, Bridge, and Export Credits were apparently wrong in finding that a breach of contract was necessary. Perhaps it can be argued that Australian judges are not required to justify departures from United Kingdom law; however, it is suggested here that the obligation does arise when the High Court of Australia, less than 10 years ago, expressly confirmed the correctness of the leading United Kingdom case.

Furthermore, the judgment in Andrews, with respect, does not represent a significant effort to reconcile the finding in that case with previous Australian High Court authority. The Court in Andrews did not discuss the IAC case in detail, where all members of the Court decided that the jurisdiction was limited to cases where the party seeking relief had been in breach. Nor did the Court discuss the $O$ 'Dea case in any detail, although some judges in that case had expressed similar views to that in IAC. It did discuss the $A M E V$ case in five paragraphs, and endorsed the opinion stated by the single judge in the Interstar case (Brereton $\mathrm{J}$ ) that Mason and Wilson $\mathrm{JJ}$ in $A M E V$ did not mean to suggest that relief against penalties was limited to cases in which the party seeking relief was in breach of contract. ${ }^{80}$ In fact, in the $A M E V$ decision, ${ }^{81}$ those judges quoted with approval English authority stating expressly that the jurisdiction to relieve against penalties was limited to cases where the party seeking relief had breached the contract. In Legione, Mason J had expressly defined a penalty as being a punishment for non-observance of a term of the contract. ${ }^{82}$ The Court in Andrews did not address the views of some judges and commentators who had a different view of what Mason and Wilson JJ said in $A M E V$, or the views of other judges in that case, a majority of whom found to the contrary of what the High Court decided in Andrews.

\section{$1 \quad$ Practical Difficulties}

Quite apart from the failure to reconcile the decision in Andrews with previous case law, other difficulties with the decision are apparent. Great care must be taken with the penalties doctrine, anomalous as it is in a general contracting environment where the courts are traditionally reluctant to intervene in the voluntarily made arrangements between private parties. Such arrangements normally give effect to parties' assessments of what the contract is worth to them, whether they are adequately compensated for the risks the

\footnotetext{
${ }^{80}$ Andrews (2012) 86 ALJR 1002, [64]-[68].

${ }^{81}$ AMEV (1986) 162 CLR 170, 184.

${ }^{82}$ (1983) 152 CLR 406, 445.
} 
contract requires them to take on, and so forth. ${ }^{83}$ The theory, at least, is that the contract reflects a complex exchange of promises, each party being satisfied, having understood its own promises and those of the other side, that the deal is to its advantage. The economic assumption is that individuals are rational utility maximisers who are able to adequately weigh the benefits and risks of the transaction, who can negotiate freely and who have adequate information by which to judge their position. The law allowing a court to set aside a clause in the contract that it believes to be a penalty is not consistent with this basic contractual paradigm. Frankly, one wonders about the wisdom of extending an already anomalous principle any further than its existing boundaries; yet this is what the Court did in Andrews.

However, perhaps what is more to be regretted in the decision in Andrews is that the High Court, which does not get to consider the doctrine very often, failed to take the opportunity to fundamentally review the law in this area. It declined to consider whether there should remain a place in the general law for the doctrine forbidding penalties, or whether the position could be taken that there is now sufficient protection elsewhere in the law (whether that protection be under a statute such as the Australian Consumer Law or under the general law such as the doctrine relating to unconscionable conduct) and that the ancient doctrine regarding penalties has had its day. Obviously, at the time the law regarding penalties was developed by the equity courts these alternatives did not exist. Now that they do, perhaps the answer to the perceived problem of unfair pre-determined damages clauses is to be found in those regimes, rather than in a principle created many centuries ago in very different circumstances. The remainder of the article will focus on whether the High Court, rather than expanding the doctrine, ought to have subsumed it into other remedies, which may themselves require some modification.

\section{Unconscionability}

The development, in the general law and in statute, of the doctrine of unconscionability reflects the recognition by the lawmakers that unadulterated freedom of contract does not reflect the realities of contract-formation today, if indeed it ever did. We need more than a doctrine that says that if a party has acceded to the terms of a contract, then it is bound by them. We know that sometimes a party has not truly given consent to the terms of a transaction, because it was being influenced by another, or did not understand the nature of the contract. We know that sometimes parties are operating on a false premise when they agree to terms. We know that, on many occasions, one party to the contract has substantial bargaining power, and can leverage this

${ }^{83}$ This is often expressed in the maxim that consideration need not be adequate: see, eg, Alexander $v$ Rayson [1936] 1 KB 169, 182. 
power into the creation of contracts on terms very favourable to itself. The law needs to respond to these realities in the world of contract.

The principle of unconscionability has become the primary general law response to these realities. ${ }^{84}$ It necessarily operates in a confined space. There is understandable concern that, above all else, those dealing with contracts value certainty, and any legal principle that allows a court to set aside a signed agreement between parties could potentially negate the very thing that a completed contract promises to deliver. This explains courts' reticence to develop the principle of unconscionability 'too much'. ${ }^{85}$

The venerable distinction between substance and procedure is evident in the courts' approach in this area. Generally, the Australian courts are most likely to apply the doctrine of unconscionability where some procedural unfairness is involved in the formation of the contract. The leading example is the Amadio case $^{86}$ involving pressure that had been brought to bear upon a poorly educated elderly couple with little experience in business. The court set aside the contract formed in such circumstances on the basis of unconscionable conduct. The court framed the principle as applying where one party to the contract is at a special disadvantage, and the other, knowing of the special disadvantage, proceeds to exploit that disadvantage. Subsequently, the High Court has taken a relatively narrow view of these requirements, emphasising that the disadvantage must be 'special', and refusing to accept evidence that

\footnotetext{
${ }^{84}$ It is beyond the scope of this article to pursue an argument that the doctrine of good faith might be used in this context. However, see Carter and Peden, above n 57, 155; Elisabeth Peden, 'When Common Law Trumps Equity: The Rise of Good Faith and Reasonableness and the Demise of Unconscionability' (2005) 21 Journal of Contract Law 226; Bryan Horrigan, 'The Expansion of Fairness-Based Business Regulation - Unconscionability, Good Faith and the Law's Informed Conscience' (2004) 32 Australian Business Law Review 159; Liam Brown, 'Impact of Section 51AC of the Trade Practices Act 1974 (Cth) on Commercial Certainty' (2004) 28 Melbourne University Law Review 589; James McConvill and Mirko Bagaric, 'The Yoking of Unconscionability and Unjust Enrichment in Australia' (2002) 7 Deakin Law Review 225. Nor does the article consider whether the principle of unjust enrichment might be utilised to deal with clauses in contracts argued to be penalties.

${ }^{85}$ Brennan J in Stern v McArthur (1988) 165 CLR 489, 514: 'If unconscionability were regarded as synonymous with the judge's sense of what is fair between the parties, the beneficial administration of the broad principles of equity would degenerate into an idiosyncratic intervention ...' . See also K Mason, 'Restitution in Australia' in Paul Finn (ed), Essays on Restitution (1990) 1, 41 where Mason called on judges to 'rein in unconscionability lest it become an entirely unruly horse'. See further Dal Pont G, 'The Varying Shades of Unconscionable Conduct - Same Term, Different Meaning' (2000) 19 Australian Bar Review 135, 138: 'The purpose and role of the doctrine of unconscionability is not to arm the courts with a general power to set aside bargains simply because, in the eyes of the judges, those bargains appear to be unfair, unjust, onerous, harsh or unconscionable'.

${ }^{86}$ Commercial Bank of Australia v Amadio (1983) 151 CLR 447.
} 
one party has taken advantage of a superior bargaining position as being sufficient to attract the doctrine. ${ }^{87}$

The courts have been much less eager to intervene on the basis of unconscionability when the argument regarding 'unfairness' occurs not in relation to events leading to the formation of the contract, but in relation to the actual terms of the contract. ${ }^{88}$ This reluctance has carried through to consideration of the statutory rules regarding unconscionability, ${ }^{89}$ despite express recognition in these rules that interpretation of the statutory principles regarding unconscionability should not necessarily be restricted by the common law conception. ${ }^{90}$ The Full Federal Court was adamant, in considering the previous statutory rules regarding unconscionability, that:

Before s 51AA, s 51AB or s 51AC will be applicable, there must be some circumstance other than the mere terms of the contract itself that would render reliance on the terms of the contract 'unfair' or 'unreasonable' or 'immoral' or 'wrong'. 91

This statement may be equally applicable to the interpretation of the relevant provisions of the Australian Consumer Law. While section 21(4)(c) specifically encourages the court to consider substantive unconscionability,

\footnotetext{
${ }^{87}$ Australian Competition and Consumer Commission v CG Berbatis Holdings Pty Ltd (2003) 214 CLR 51, 64-5 (Gleeson CJ), 77 (Gummow and Hayne JJ), 105 (Callinan J); contra Kirby J (at 96). See also Rick Bigwood, 'Curbing Unconscionability: Berbatis in the High Court of Australia' (2004) 28(1) Melbourne University Law Review 203.

${ }^{88}$ Paul O'Shea, 'All's Fair in Love and War - But Not Contract' (2004) 23 University of Queensland Law Journal 226, 231; S Smith, 'In Defence of Substantive Fairness' (1996) 112 Law Quarterly Review 138; James J Davidson, 'Unfair Contract Terms and the Consumer: A Case for Proactive Regulation?’ (2007) 15 Competition and Consumer Law Journal 74.

${ }^{89}$ These are found now in the Competition and Consumer Act 2010 (Cth) sch 2 (known as the 'Australian Consumer Law') ss 20-22; formerly ss 51AA-AC of the Trade Practices Act 1974 (Cth).

${ }^{90}$ Section 21(4) of the Australian Consumer Law.

${ }^{91}$ Hurley v McDonald's Australia Ltd [1999] FCA 1728, [31]; see also Nicholson J in Australian Competition and Consumer Commission v Lux Pty Ltd [2004] FCA 926, [94]: ‘To ground a finding of contravention of s $51 \mathrm{AB}$, there must be some circumstance other than the mere terms of the contract itself which renders reliance on the terms of the contract unconscionable'. See also Attorney-General of NSW v World Best Holdings Ltd (2005) 63 NSWLR 557, [121]: 'Unconscionability is a concept which requires a high level of moral obloquy. If it were to be applied as if it were equivalent to what was "fair" or "just", it could transform commercial relationships in a manner which [was not intended]'; Charles Rickett, 'Unconscionability and Commercial Law' (2005) 24 University of Queensland Law Journal 73.
} 
some commentators continue to think that the approach expressed in Hurley is applicable to the new provisions. ${ }^{92}$

Carlin has reviewed the interpretation of the Contracts Review Act 1980 (NSW), which allows the court to make orders if it believes the contract to be 'unjust', using factors broadly similar to general principles of unconscionability. He has found that of 18 cases studied, in only one of them was the basis of the decision a finding that a specific clause was unfair; in all other cases, procedural unfairness was the basis of the intervention. ${ }^{93}$

Reflecting on the courts' reticence in this area, Corones and Christensen observe:

While courts are able to consider substantive unconscionability under the Act, they rarely do so without also considering the impact of procedural unconscionability. The reliance upon procedural unconscionability severely limits the ability of the Act to deal directly with unfair terms in consumer contracts. $^{94}$

It is thus suggested that, instead of reinforcing the narrow view that has until now been taken to the question of 'unconscionability' as a basis for contractual relief, the High Court should be prepared to allow consideration of the content of substantive clauses, rather than only matters of procedure. If it did so, the Court could subsume the rule forbidding penalties into the broader doctrine of unconscionability, removing the anomalous rule regarding penalties, a rule whose raison d'être has arguably passed with the advent of common law and statutory recognition of unconscionability as an organising principle.

The links between unconscionability and the law forbidding penalties have been made before, by the judges themselves. In Dunlop, a decision that the High Court expressly approved in Ringrow, Lord Dunedin stated that an

\footnotetext{
${ }^{92}$ Russell Miller, Australian Competition and Consumer Law Annotated (2012) 1693 refers to the Hurley comments in the context of ss 21 and 22 of the Australian Consumer Law.

93 Tyrone M Carlin, 'The Contracts Review Act 1980 (NSW) - 20 Years On' (2001) 23 Sydney Law Review 125; Ben Zipser, 'Unjust Contracts and the Contracts Review Act 1980 (NSW)' (2001) 17 Journal of Contract Law 76; Lynden Griggs, 'The (Ir)rational Consumer and Why We Need National Legislation Governing Unfair Contract Terms' (2005) 13 Competition and Consumer Law Journal 51, 62; Helen Saunders, 'Relief From Unconscionable Contracts: The Contracts Review Act 1980 (NSW) and the "Unwritten Law"” (2007) 29 Australian Bar Review 290.

${ }^{94}$ Stephen Corones and Sharon Christensen, Comparison of Generic Consumer Protection Legislation (4 September 2007) Productivity Commission, 128 <http://www.pc.gov.au/ __data/assets/pdf_file/0008/73691/consumerprotectionlegislation.pdf $>$.
} 
amount was a penalty if it was 'extravagant or unconscionable' in amount. ${ }^{95}$ The same words were used to describe a penalty in Clydebank Engineering ${ }^{96}$ and Webster $v$ Bosanquet. ${ }^{97}$ Six judges of the High Court in Ringrow agreed that a penalty was something that was 'unconscionable in amount'. ${ }^{98}$ Several members of the High Court in $A M E V$ used the word 'unconscionable' in describing the nature of a penalty in the current context, ${ }^{99}$ as did Deane $\mathrm{J}$ in O'Dea. ${ }^{100}$ However, it has not yet been suggested by the judges that the principle of relief against penalties be subsumed within the organising principle of unconscionability, as has been suggested in this article.

A case example somewhat analogous to the position favoured here is Olex Focas $v$ Skodaexport. ${ }^{101}$ The case involved the enforceability of performance bonds, similar in nature to liquidated damages clauses in as far as they are intended to ensure performance of the contract and provide security to one of the parties in the event of breach. Attempted access to the performance bond was challenged on the basis that the party seeking to do so was engaged in statutory unconscionable conduct. Batt $\mathrm{J}$ of the Victorian Supreme Court found that this allegation was partly made out. The basis of the finding, in relation to the advance payments known as a 'mobilisation guarantee', was that it was unconscionable to insist on the strict contractual right of guarantee when the amount secured by the guarantee had largely been repaid. ${ }^{102} \mathrm{By}$ analogy to this decision, it might be argued that for a party to insist on the payment of an amount specified in the contract between the parties as an agreed genuine pre-estimate of damage, when that amount is shown to be

\footnotetext{
${ }^{95}$ [1915] 1 AC 79, 87 (emphasis added).

${ }^{96}$ [1905] AC 6, 10.

${ }^{97}$ [1912] AC 394, 398.

${ }^{98}$ (2005) 224 CLR 656, 669, [32]. See also P D Baron, 'Confused in Words: Unconscionability and the Doctrine of Penalties' (2008) 34 Monash University Law Review 285; Paula D Baron, 'The Doctrine of Penalties and the Test of Commercial Justification' (2008) 34 University of Western Australia Law Review 42, 58; Elizabeth V Lanyon, 'Equity and the Doctrine of Penalties' (1996) 9 Journal of Contract Law 234, 242; Aristides N Hatzis, 'Having the Cake and Eating it Too: Efficient Penalty Clauses in Common and Civil Contract Law' (2002) 22 International Review of Law and Economics 381. On the connection between procedural unconscionability and penalties, see Samuel A Rea Jr, 'Efficiency Implications of Penalties and Liquidated Damages' (1984) 13 Journal of Legal Studies 147.

${ }^{99}$ (1986) 162 CLR 170, 190, 193 (Mason and Wilson JJ), 198, 201 (Deane J), 218 (Dawson J).

100 (1983) 152 CLR 359, 399-400.

101 [1998] 3 VR 380.

102 Ibid 404 (the decision was confirmed by the Victorian Court of Appeal). On the other hand, the court suggested in Clough Engineering Ltd v Oil and Natural Gas Corporation [2008] FCAFC 136, [138] that the doctrine of unconscionability should have very restricted operation in the context of performance bonds in contracts. See further Veno Panicker, 'Autonomy, Unconscionability and Entitlement in the Operation of Performance Bonds in Australia' (2009) 25 Building and Construction Law Journal 230.
} 
clearly disproportionate to the amount that the innocent party would suffer from the breach, could also be seen to be unconscionable. ${ }^{103}$

At a slightly higher level of abstraction, there is precedent supportive of the view that forfeiture of an interest, ${ }^{104}$ though legally permissible under the contract, may be unconscionable in the particular circumstances of the case, ${ }^{105}$ whether or not exceptional circumstances exist. ${ }^{106}$ A relevant example of this is where, if the innocent party were allowed to exercise the forfeiture right in the contract, that party would receive a windfall benefit, something that is beyond what is necessary to achieve the purpose of the forfeiture clause. ${ }^{107}$ It is suggested here that the general law doctrine of unconscionability should embrace the law allowing penalties to be struck out of contracts. ${ }^{108}$

In relation to the statutory law of unconscionability, and accepting that it need not be identical to the general law doctrine, it is submitted that a court could incorporate questions regarding penalties into questions of unconscionability quite readily, in terms of section 21 of the Australian Consumer Law. Section 22(1)(a) specifically allows the court to assess the relative strength of the parties' bargaining positions in assessing unconscionability. Regarding the provision of goods or services, section 22(1)(b) specifically allows the court

103 Or, more controversially, that it would be unconscionable to insist on payment of the amount stated in the liquidated damages clause, where the actual loss suffered by the party wronged by the breach was substantially different from (lower than) the amount in the predetermined clause.

104 The author concedes that penalties differ from forfeitures, but the principles are in many ways similar. The leading equity textbook by R P Meagher, J D Heydon and M J Leeming, Equity: Doctrines and Remedies (Butterworths LexisNexis, $4^{\text {th }}$ ed, 2002) deals with them in the same chapter, at 577.

${ }^{105}$ Legione (1983) 152 CLR 406, 429 where Gibbs CJ and Murphy J concluded that, because the guilty party's breaches were neither wilful not serious, '[t]o enforce the legal rights of the vendors in these circumstances would be to extract a hard and excessive penalty for a comparatively trivial breach'. Mason and Deane JJ accepted that there would be occasions when it might be 'unconscionable' for the innocent party to exercise a forfeiture right: at 447. Though their Honours insisted that forfeiture was distinct from penalty, there is no reason to think that they would disagree that it might also be unconscionable for the innocent party to exercise a right that amounted to a penalty.

106 In Tanwar Enterprises Pty Ltd v Cauchi (2003) 217 CLR 315, 335 [59] Gleeson CJ, McHugh, Gummow, Hayne and Heydon JJ rejected the need for 'exceptional circumstances' in order that equity's jurisdiction in the area of unconscionability be enlivened.

107 Stern v McArthur (1988) 165 CLR 489, 527 (Deane and Dawson JJ), 541 (Gaudron J). Mason CJ (dissenting) also accepted the unconscionability doctrine in this context: at 501. Only five judges sat on this case.

108 This position is also reached by Kevin E Davis, 'Penalty Clauses Through the Lens of Unconscionability Doctrine: Birch v Union of Taxation Employees, Local 70030' (2010) 55 McGill Law Journal 151, 153; see also Larry A DiMatteo, 'Penalties as Rational Response to Bargaining Irrationality’ (2006) Michigan State Law Review 883, 886. 
to consider whether one party is being required to comply with conditions not reasonably necessary to protect the legitimate interests of the other. In the specific context of penalty clauses, it could be argued that a clause would fall squarely within section 22(1)(b) if it required that a party to the contract pay the other party to the contract a sum if certain events occurred, and if that sum were out of all proportion to the loss that the payee could conceivably suffer if that event were to occur. In that case, it would be unnecessary to protect legitimate interests, and could thus be struck out by the court as being unconscionable. $^{109}$

\section{CONCLUSION}

This article has argued that the High Court missed an important opportunity in the Andrews case to re-cast the law with respect to penalties and liquidated damages in contracts. The actual decision reached was contrary to the orthodox position in the United Kingdom, Canada and the United States, and contrary to several previous High Court authorities, as well as to the practice of law, as evidenced by numerous standard form contracts. This in itself does not make the decision 'wrong', but a clear case needed to be made of the deficiencies in the previous law, and how the new formulation would address those deficiencies and provide better contractual outcomes. This clear case was not made by the High Court in Andrews, and the decision does not reflect significant appreciation of the fact that a departure from the previously understood position was being made, nor does it provide a rationalisation for such a change. The article has argued that the High Court would have done much better to thoroughly revisit the need for the distinction between penalties and liquidated damages. It has further argued that other doctrines which have developed since equity courts began to provide relief against penalties are better equipped to deal with such arguments. The High Court should have subsumed the past distinction between penalties and liquidated damages into the principle of unconscionability as an organising principle. This would not have been a great leap, since many of the cases to which this article has referred in fact discuss unconscionability principles in the context of penalties. However, the law needs to abandon its traditional reluctance when dealing with unconscionability principles to consider substantive unconscionability, while continuing to uphold freedom of contract, and the need for certainty as important values in this area.

\footnotetext{
${ }^{109}$ Like the unfair contracts regime of the Act, s 24(1)(b) of the Australian Consumer Law allows the court, in deciding whether a term of a contract is fair or not in the context of a standard form contract, to consider whether the term is reasonably necessary to protect the legitimate interests of a party to the contract.
} 
